ÉGYPTE monde arabe

\section{Égypte/Monde arabe}

$11 \mid 2014$

Ville et révolution en Égypte

\title{
The Politics and Governance of Implementing Urban Expansion Policies in Egyptian Cities
}

\section{Mohamed Nada}

\section{(2) OpenEdition \\ 12 Journals}

\section{Electronic version}

URL: https://journals.openedition.org/ema/3294

DOI: $10.4000 /$ ema.3294

ISSN: 2090-7273

\section{Publisher}

CEDEJ - Centre d'études et de documentation économiques juridiques et sociales

\section{Printed version}

Date of publication: 6 April 2014

Number of pages: $145-176$

ISBN: 978-2-905838-84-1

ISSN: 1110-5097

\section{Electronic reference}

Mohamed Nada, "The Politics and Governance of Implementing Urban Expansion Policies in Egyptian Cities ", Égypte/Monde arabe [Online], 11 | 2014, Online since 09 April 2014, connection on 07 July 2022. URL: http://journals.openedition.org/ema/3294 ; DOI: https://doi.org/10.4000/ema.3294 


\section{THE POLITICS AND GOVERNANCE OF IMPLEMENTING URBAN EXPANSION POLI- CIES IN EGYPTIAN CITIES}

RÉSUMÉ

La gestion de la croissance urbaine est essentielle à la prospérité et à la durabilité des villes, même si l'on a peu d'éléments sur les facteurs qui entravent l'application des mesures de régulation de l'urbanisation. Cette recherche se penche sur ces facteurs à travers trois dispositifs mis en place par le gouvernement égyptien : limite de croissance urbaine, planification détaillée dans les zones d'expansion urbaine, et prélèvement sur les plus-values. La collecte de données a été effectuée selon une méthode qualitative. La démarche s'intéresse particulièrement aux capacités, comportements, interactions des acteurs à différents niveaux, ainsi qu'au rôle des agencements institutionnels formels et informels et à l'influence de contextes politiques plus vastes sur les comportements et modes d'interaction des acteurs, en particulier après la Révolution du 25 janvier.

La recherche conclut à l'intrication étroite des facteurs faisant obstacle à I'application des politiques étudiées. Parmi ces obstacles, on trouve principalement une longue tradition de centralisation, une faible coordination entre politiques mises en place au niveau national, de faibles capacités organisationnelles au niveau local, un cadre légal ambigu et obsolète, et un manque de confiance dans les gouvernements élus et les fonctionnaires de l'échelon local. La Révolution du 25 janvier a accru l'incapacité du gouvernement à appliquer les politiques étudiées et a encouragé les propriétaires à les ignorer. 


\section{MOTS CLÉS :}

Régulation de l'expansion urbaine, villes égyptiennes, limites urbaines, planification, prélèvement sur les plus-values.

\section{ABSTRACT}

Managing urban expansion is very critical to cities' prosperity and sustainability, however very little is known about the factors that hinder the implementation of policies formulated to manage urban expansion. This research explore these factors in relation to three policies implemented by the Egyptian government, namely the application of: urban growth boundary, detailed planning in urban expansion areas, and betterment levy. The key methods used in the primary data collection were qualitative in nature. The research gives special emphasis to the impact of actors' capacity, behavior, and modes of interaction at the different levels, as well as the role of formal and informal institutional set-up and wider policy setting on actors' behavior and modes of interaction, especially after the 25th of January revolution. The research concluded that there are number of interlinked factors hindering the implementation of policies investigated, most importantly are the long standing history of centralization, weak coordination between relevant policies at the national level, weak organizational capacity at the local level, ambiguous and outdated legal framework, and lack of trust in local government elected members and appointed officials. The 25th of January revolution intensified the inability of government to implement the policies examined and escalated the lack of interest in implementing them from the view point of land owners.

\section{KEYWORDS:}

Urban expansion policies, Egyptian cities, Urban Growth Boundary, planning expansion areas, betterment levy. 
here is a near consensus among scholars, policy makers, and urban residents that managing urban expansion is crucial. What is controversial, however, is whether it should be restricted or encouraged (Myers, 2001). Most views call for the adoption of policies that are geared towards achieving "sustainable urban expansion", "smart growth", and "compact cities" by increasing existing cities' densities to reasonable levels, encouraging infill, re-use of infrastructure and previously developed land, implementing zoning and land subdivision regulations, placing urban growth limits, and land conservation measures (Cervero, 1995; Thomas \& Cousins, 1996; Levinson \& Kumar, 1997; Schwanen, Dijst, \& Dieleman, 2004; Angel et. al., 2005).

The proper application of these policies has been considered crucial as they are directly related to the achievement of sustainable development and a wide spectrum of environmental, economic, and social issues, such as environmental conservation, city prosperity, quality of life, taxpayer protection, transportation planning, urban revitalization, environmental justice, affordable housing, and others. However, despite the importance of the proper application of these policies, literature tends to focus on describing them rather than evaluating their impact or assessing the factors that affect their implementation (Hollis and Fulton, 2002; Bengstona, et. al., 2004).

Three groups of policies could be identified as aiming at managing cities' urban expansion, they are: policies centering on limiting the rural-urban migration to some cities; policies aiming at managing the distribution of urban populations among cities; and policies focusing on managing urban development in individual cities and metropolitan areas (Angel et. al, 2005).

Several policy instruments could be recognized, most prominently: public acquisition of land for managing urban growth and protecting open space; policy instruments addressing market failures by employing incentives or disincentives that affects behavior towards urban expansion (such as the introduction of development taxes, congestions tolls, or impact fees); policy instruments adopting a regulatory "Command and Control" approach, which entails an authoritative relationship between the individuals or groups being regulated and the government through the employment of sanctions in case of noncompliance (such as applying rate of growth controls, growth-phasing regulations, adequate public facility ordinances, up-zoning or small-lot zoning, minimum density zoning, greenbelts, and urban growth boundaries); 
and finally through informational or awareness campaigns aiming at influencing people behavior (this instrument is not commonly used).

\section{URBAN EXPANSION AND URBAN EXPANSION POLICIES FOR EGYPTIAN CITIES}

The vast majority of cities in Egypt are located within the fertile Nile river valley and delta. This leaves about 93\% of Egypt's land vacant. This fact has significant ramifications: the increase in urbanization and the continuous population growth occur at the expense of existing agricultural land. The pressure of urban expansion was further escalated by the inability of the government to formulate efficient and integrated policies and plans that channel urban expansion towards new cities (also known as desert cities).

The process of rapid urbanization was also accompanied by informal urban development, which has become a predominant feature of urban expansion in the last four decades. For instance, Greater Cairo in the 1950s was entirely formal, with a population of around 2.5 million inhabitants. However, after the July 1952 Revolution, urbanization accelerated significantly under Naser's socialist government which saw itself as the vanguard of development. As a result of informal urban expansion between 1981 and 1988, Cairo proper encroached on 340 square kilometers of fertile agricultural land (EI Araby, 2002), and this trend is continuing and an alarming rate of $0.8 \%$ annually.

Despite the importance of implementing policies aiming at managing urban expansion in countries of the developed and the developing world, very limited literature has been focused on the determinant factors affecting their implementation, especially in the context of cities of the developing world. This paper will aim at addressing this gap by assessing the key factors that are hindering the materialization of the intended outcomes of three policies adopted by the Egyptian government to manage urban expansion within existing cities, namely the application of Urban Growth Boundary through the process of undertaking city or village strategic plans (a regulatory policy); undertaking detailed plans for urban expansion sites specified by the city strategic plan (a regulatory policy); and application of a betterment levy to capture the increase in value in the land that benefited from the change in the land use as a result of being earmarked as urban expansion areas in the city strategic plan (a market based policy). 


\section{THE SCOPE OF THE RESEARCH AND THE RESEARCH METHODOLOGY}

The aim of this paper is to explore power relationships and modes of interaction between the key actors involved in the implementation of urban expansion polices in Egypt. Emphasis will be given to the role exerted by the formal and/or informal institutions in shaping, channeling, or constraining the choices of actors at the different levels, as well as the impact of the wider policy framework on the implementation of the policies under investigation.

Three key methods have been used. First, a desktop review of the different laws and regulations governing the implementation of the three polices, as well as the legislation stipulating the role of the different actors involved in their implementation. The most important pieces of legislation reviewed were: the building Law $n^{\circ} 119$ for the year 2008 regarding the implementation of the application of the UGB and the detailed plans; the betterment levy Law $n^{\circ} 222$ for the year 1955; property expropriation Law $\mathrm{n}^{\circ} 10$ for the year 1990; the local administration Law $\mathrm{n}^{\circ} 43$ for the year 1979 which explains the roles of governors, executive councils of the different local administrative units, and the elected local popular councils; and Law $n^{\circ} 143$ for the year 1964 regarding property registration authority.

The other two methods were semi-structured interviews and focus group discussions with key informants from the government, smallscale landowners (defined in this research as owners having less than one feddan), and small-scale informal private developers. 50 interviews and 12 focus group discussions were conducted between April and December 2013. Key informants from the government included at the national level: the Minster of Local Development (MoLD) and 3 senior officials from the Ministry; the Chairman of the General Organization of Physical Planning (GOPP) and 6 senior officials from the organization; the previous director of the Property Registration Authority; the director of the Local Administration Finance Section at the Ministry of Finance and 2 senior officials from the Ministry. At the regional level, 4 directors of the regional center of the GOPP were interviewed.

Finally, at the local level, the key informants interviewed were: the governors of Luxor and Qalyubia; the general secretary of Luxor, Ismailia, Garbaya, and Fayoum; the head of the General Department for Planning and Urban Development (GDPUD) of Fayoum, Beni Suef, Ismailia, Qalyubia, and Garbaya; the head of Property Registration Authority at Fayoum and Qalyubia and 2 senior officials in each office, and the head of the Finance Directorate at the governorate level in Ismailia and Fayoum and 2 key informants at the Finance Department at the city level in each governorate. 
Interviews and focus group discussions with key urban planning experts were also conducted, including interviews with: Dr. Abou Zeid Ragah (the former chairman of the Housing and Building Research Institute and currently a member of the Supreme Council of Planning and Urban Development (SCPUD); Dr. Ahmed Youssery (Dean of Faculty of Urban and Regional Planning - Cairo University); Dr. Ahmed Soliman (professor at Faculty of Engineering - Alexandria University); Dr. Mohamed Salheen (assistant professor at Ein Shams University), and Dr. Ayman Hashem (Faculty of Engineering, Assuit University).

The fourth section of this paper presents the key actors involved in the implementation of urban expansion policies in Egypt. The fifth section presents the empirical findings for each policy investigated in this research, and the sixth section outlines a synthesis of the different variables that have impacted the implementation of these polices, and finally the last section concludes the paper and highlights areas for future research.

\section{KEY ACTORS INFLUENCING THE IMPLEMENTATION OF URBAN EXPANSION POLICES IN EGYPT}

The key actors involved the implementation of polices aiming at managing urban expansion in existing cities according to the current legal and institutional framework are:

a) The SCPUD is chaired by the Prime Minister, relevant ministers, and urban planning experts. The SCPUD is mandated (among other functions) to: i) adopt general goals and policies for planning and urban development at the national level; ii) coordinate between ministries and bodies concerned with urban development and state land use; iii) suggest and to express opinion regarding draft laws pertaining to urban development; iv) evaluate the general results of implementing the national strategic plan, the regional strategic plans, and; v) approve the strategic plans for national and regional urban development and governorate plans.

b) The GOPP and its regional offices. The GOPP is the state agency responsible for developing the general policy for planning and sustainable urban development. The GOPP reports to the Minster of Housing, Utilities, and Urban Development and acts as the technical secretariat of the SCPUD. The GOPP also has a mandate to : i) develop the national program for the preparation of strategic plans for urban development on the different levels; ii) prepare the strategic plans for urban development on the national, regional, and governorate levels as well as the general strategic plans for cities and villages; iii) review, endorse, and 
monitor the implementation of general strategic plans for cities and villages and their urban areas; iv) improve and develop the capabilities of the urban planning departments in local units; and v) develop the implementation mechanisms of the strategic plans for the different levels and detailed plans. The GOPP has regional offices in each of the seven economic regions. These centers are responsible for undertaking the competencies of GOPP in the region and provide technical assistance to the General Planning and Urban Development Departments at the governorate level. The Center shall also follow-up the preparation and implementation of city and village plans in such governorates.

c) The heads of the Local Administrative Units (LAUs): Egypt has five types of LAUs. They are the governorate, the city region or the district (Markaz), the city, the neighborhood or the urban district (Hay), and the local village administration. For each of these units, there is an appointed civil servant who is responsible for heading its executive council and insuring the proper implementation and provision of the different services. The Governor is the head of the LAU at the governorate level and is appointed by the president. The Prime Minister is responsible for appointing other heads of LAUs, with the exception of the head of the village who is appointed by the Governor. The accountability line between the heads of LAUs is hierarchal whereby the head of the lower LAU reports to the higher. In each governorate there is a GDPUD which is mandated to prepare detailed plans for cities and villages, through experts and consultants that are registered at the GOPP. The head of this department reports to the governor.

d) The Local Popular Councils (LPCs): For each LGU, there is a LPC which is formed from directly elected representatives. The main function of the LPC is to hold the executives accountable for the delivery of the basic services and infrastructure in accordance with the competencies granted for each LGU. They are also responsible for approving the proposed budget and the proposed socio-economic plan of their administrative unit, as well as the detailed plans, including the plans for urban expansion areas. Prior the $25^{\text {th }}$ of January Revolution, the vast majority of LPC members were from the ruling National Democratic Party, which was abolished along with these councils just after the Revolution.

e) The private sector involved in urban expansion over agricultural land is predominantly composed of small-scale to moderatescale constructors. Very limited efforts have been dedicated to document the modality by which they function on the ground and the factors that affect their operation. 


\section{MAIN POLICES ADOPTED BY THE EGYPTIAN GOVERNMENT TO MANAGE URBAN EXPANSION}

\section{Applying Urban Growth Boundaries (UGB)}

Urban Growth Boundaries (UGBs) is a common planning tool used to demarcate limits for urban expansion over a particular period of time, generally 20 years (Calthorpe \& Fulton, 2001). This policy is mainly used to control urban sprawl and leap-frogging by encouraging densification and in-fill development, and to reduce the cost of infrastructure provision for the new expansion areas. More importantly in the Egyptian context, this policy aims at halting illegal urban expansion on precious agricultural land.

According to building law, the process of specifying the delineation of the UGB is done as an integral aspect of undertaking the city strategic plan and it circumscribes the entire urbanized area and demarcates new areas that will be added to the city for future urban expansion. These newly added areas are added based on an estimate of the expected population growth of the city in the coming 20 years as well as its current density.

According to the building law, the process of undertaking the city strategic plan and the specification of the UGB is administered by the regional office of the GOPP through consultants and in full participation of development partners (specified in the law as being LPC, the civil servants at the local government level, civil society groups, and the private sector). The draft strategic plans for the cities and villages are presented to the community in a public consultation, presented to the governor and the LPC, and then approved by the Minister of Housing. The building law also stipulated that any developmental activity outside the UGB is considered illegal, unless a special permission was granted by the SCPUD. Governors are also authorized to issue a decree for demolishing violating construction activities on the expenses of the violator.

In practice, the process of undertaking city strategic plans and the identification of UGB faces several difficulties in implementation. For instance, in the Greater Cairo Region, only six cities out of the 21 cities in peri-urban Cairo had an approved strategic plan and an approved UGB, while there are 13 cities in various stages of undertaking strategic plans, and there are two cities that the GOPP has not yet started working on.

Key officials at the local government level have expressed their concerns regarding the delay in developing and approving the strategic plans. According to one official: 
"we started the process of undertaking the plan in 2009 and until today it has not been finalized. This puts us under pressure with landowners in the urban expansion areas as they would require us to start a process of undertaking a detailed plan which will allow them to undertake land subdivision and build formally. The delay in undertaking the strategic plans and the dramatic increase in the prices of land in the urban expansion areas drives land owners to build informally".

The sweeping change resulting from the $25^{\text {th }}$ of January Revolution has had a significant impact on the spread of informal areas on the fringes of cities and villages. A Governor highlighted that:

"before the revolution [referring to the $25^{\text {th }}$ of January] we were facing real difficulty in halting illegal building outside the UGB, but after the revolution things got really worse and governors feel powerless amid the huge pressure exerted by land owners and the very limited power of the state to ensure the rule of law".

The feeling of powerlessness by the governors after the $25^{\text {th }}$ of January has resulted from mutually enforcing factors. Among these factors was the rapid realization of citizens and traditionally non-vocal actors that they can collectively achieve substantial change from central or local government if they were able to aggressively lobby the Governors, or other senior governmental officials, through protests. From the other side, Governors view the central government itself as being in a very weak position and not being able to backstop them if they took decisions that create tension at the local level, even if these actions were aiming at insuring the rule of law or the achievement of the public good. The high mobility and coverage of media, especially satellite channels, in broadcasting what happens at the local level was perceived by the Governors and the Governorates' Secretary Generals interviewed, to be unprecedented, and further escalating the lobbing power of citizens and increasing the vulnerability of local and central government to popular pressure. Social media was also suggested to play a significant role in bringing citizens together to lobby local government, as well as the live broadcasting of what occurs on the ground through cell phones and other available hardware.

One of the senior local government employees stated that what has occurred in the governorates after the revolution is:

"shifting from one extreme to the other... Citizens have shifted from a total sense of helplessness and apathy to the total opposite where they feel that anything can be changed if they are able to come together... this sudden shift was not accompanied by an adequate understanding of 
their rights nor the realization that with rights comes responsibilities as well."

Governors were forced amid these pressures to make compromises to citizens' call for taking action, such as pressuring the central government to expand the UGB, or in other cases making compromises by abstaining from taking action such as overseeing the illegal development occurring inside or outside the UGB. One of the Governors stated:

"illegal building occurs just in front of my residence and I feel powerless to take action... this is really so embarrassing but this is what I am facing everyday... land owners and citizens at large become uncontrollable and they are realizing that we are not able to insure the rule of law so they want to quickly built informally and let us in the future deal with the status quo"

Many landowners were able to sense this powerlessness of local government and they felt they should utilize this opportunity. One of the land owners explained further by stating:

"informal development led to nothing but more informal development, as we see that the government is unable to stop informal development, this gives us an incentive to build illegally, and in many cases those who violated the law by building informally were indirectly rewarded by including their land in the new boundary as the state is forced to accept the reality on the ground and deal with the massive informality that became the predominant pattern in our cities".

Prof. Ahmed Soliman, a prominent academician and expert in urban planning, argued that the main factor that delays the process of undertaking the strategic plan and the demarcation of the UGB is the contradiction between the government statements and its action with respect to the implementation of decentralization. According to him, the 1971 constitution and its amendments in 2007 called for adopting decentralization and the gradual shift of competencies from the central level to the local level. However, the process of undertaking spatial planning moved from a relatively decentralized process to a very much centralized one.

The process of centralization and shifting competences from the local level to the central level is clear when comparing the building law with the law which preceded it, which is Law $\mathrm{n}^{\circ} 3$ for the year 1982, which gave the local government the responsibility of undertaking the general spatial plans for the cities and villages and the identification of the UGB through technical support from the GOPP. Prof. Soliman stated: 
"in the previous law the roles were set right. The local government led the process and the Minster of Housing should approve the final outcome. However now with the Building Law, central government is in the driving seat in the preparation and approval of the plan and local government role is restricted in providing inputs and suggestions".

Dr. Nabil Hassib, a senior urban planning expert who has substantive experience in evaluating cities' strategic plans added that centralization of the process of undertaking the strategic plan and the specification of the UGB was not only restricted to developing the plan but in coordination with key actors sharing in the decision of the delineation of the UGB. He said:

"consultants hired by the GOPP organize several meetings with local government and development partners at the local level to solicit their inputs regarding the delineation of the UGB and then they submit the recommended boundary to the GOPP, however their suggested boundary usually gets rejected by the Ministry of Agriculture or Ministry of Defense, and they are requested to change the proposed boundary again. Several requests were made to the GOPP for insuring the restrictions suggested by the different central actors are communicated to the consults and the local government before the consultation process occurs at the local level, but this was seen as being not possible".

Amid the calls for decentralization, there are several views that are critical about decentralizing the process of undertaking the cities strategic plans to the governorate level, as a result of the limited trust and the limited capacity of local government. Senior officials from the GOPP stated that:

"as a result of the change in the delineation of the UGB, some landowners could find their wealth doubled ten times as a result in changing the land use of their land from agriculture to urban... To achieve that, landowners will be taking any approach to maximize their power in lobbing the elected members and the civil servants, and even our consultants to include their land in the new UGB... If the decision was given to the local government, I am very confident that the criteria for including land in the UGB will not be based on technical criteria, but predominately based on power dynamics at the local level".

This view was not only suggested by officials from the central government, but also by many senior officials from the local government. In an interview with the Governor, he stated: 
"I am in favor of centralizing the process because if citizens felt that the power of drawing the new urban boundary became one of my competences, I can promise you that land owners will be demonstrating in front of the governorate building until all the agricultural land in the governorate change into urban usage."

Focus groups with landowners also reinforced the hesitation in decentralizing the process of undertaking the strategic plan and the delineation of the UGB, as they were skeptical the objectivity and impartiality of local government, both from the executive and the elected.

Several officials from the local government were concerned about the technical ability of local government to undertake the detailed plans. The head of the General Department of Planning and Urban Department stated that:

"if we [local government] are unable to undertake the detailed plan as stipulated in the Building Law, then it will be naive to request local government to undertake the strategic plan unless a complete reform at the local level occurred, and provision of needed human and financial resources is undertaken".

The debate around who should be specifying the new UGB is not the only debate, but also how much land should be added. In a focus group discussion with small-scale constructors involved in building residential houses, one of the constructor mentioned:

"we do not know how they decide how much land is needed for the city to expand. We are told that the land included in the new boundary should be enough for the city to grow in the coming twenty years, however the reality is that even before the boundary is approved, the whole expansion area gets sold for urban use and is being built." Another contractor added "the government should include in the new boundary at least five times more land. The prices of the square meter can jump to ten and fifteen thousand Egyptian pounds which makes the prices of the building unaffordable for even the middle class".

Key officials from the GOPP refuted this claim and argued that the area included in the boundary is calculated to insure proper density within the city according to the population forecast. In addition, they suggested that efforts should be made to limit the urban expansion on the valuable agricultural land and that if Egyptian cities in the delta and the Nile valley continued expanding with the current pattern, the agricultural land in the delta will significantly shrink which will have a 
significant impact on the economic base of these cities and the national food security at large.

In an interview with Dr. Abou Zaid Ragah, he stated that:

"all the efforts that we are doing to manage urban expansion in the existing cities are useless and Egypt has to plan for a major migration from the Nile valley towards to shores and deserts of Egypt. We have been locking ourselves in the densely populated Nile valley and we are forgetting that it is only six percent of the Egyptian land". In another interview, Dr. Ahmed Yousry suggested that "Egypt really needs a national urban policy that states where are the new areas that are suitable for urbanization and how are we going to tackle urban challenges within the existing cities".

Key informants from the GOPP highlighted the importance of having a national urban policy as the policies that are currently being undertaken are contradictory to each other and have developed without an overarching vision that direct their formulation and implementation. A senior official from the GOPP stated:

"it is really odd that the two authorities that report to the Ministry of Housing are adopting two opposing policies. From one side the NUCA is building new urban communities and aiming at providing incentives to residents and investors to relocate to these new communities, however from the other side the GOPP is expanding the UGBs of the existing cities and by doing that creating incentives for the residents of these cities to stay within them and not to move to the new cities"

The decision to violate the UGB and build over privately owned agricultural land could be attributed to several factors, including the land market, the proximity of the agricultural land to the urban fringe, the connection of the land to roads and infrastructure. However, several local government officials and landowners stated that the key factor that determine the decision to violate is the perception of land owners to the power of the Minister of Agriculture and/or the Governor in applying sanctions on the non-compliant, and they have attributed this in a number of cases to how land owners were very aware and sensitive to the change in the leadership within the Ministry or the governorate, and this leadership is always associated with the minster's or governor's competence, charisma, and the power of creating a change or stop violations. 


\section{Undertaking a detailed plan for urban expansion areas}

The detailed plan is defined by the Building law as the executive plan for the building and planning regulations. It presents the different land uses and infrastructure suggested in the city or village strategic plan. The plan also contains all integrated urban design development projects, land sub-divisions and landscaping projects whose execution is suggested in the general strategic plan.

The GDPUDis responsible for preparing the detailed plans for newly added urban expansion areas to the UGB, through experts and consultants registered at the GOPP. The governors are responsible for accrediting the detailed plans after being approved by the LPC of the governorate, and the approved plan is published in the official Egyptian gazette.

Detailed plans are crucial according to the Building Law; cities and villages will not be able to issue a statement for locations' validity for building or issue building permits without the existence of an accredited detailed plan. However, local government and citizens are facing real challenges in following the law since the vast majority of cities does not have an approved detailed plans for urban expansion areas (about ten cities have an approved detailed plan out of the 228 cities in Egypt), and the usefulness of these approved plans remains ambiguous and contentious when local government and land owners want to implement them on the ground.

The interviews with different actors at different levels illustrated that they have a mixture of complementary and opposing views regarding the reasons hindering the process of producing the detailed plans and insuring the technical accuracy and rigor of the final product. From the point of view of the governors, the law has given the local government the responsibility of undertaking the detailed plans, however the current legal and institutional framework did not insure the provision of the necessary financial resources to do this. One governor mentioned:

"the 2012 constitution stipulates that local government should be equipped with the financial resources that would allow them to perform the tasks that have been assigned to them, but in reality this does not exist. I am requested to undertake detailed plans which could cost about three million Egyptian pounds for cities in my governorate; however no one is pinpointing how I would be able to provide these needed resources".

The financial constraints are not the only challenge facing governors in undertaking these plans, but human capital is also a tremendous challenge. Most governorates do not create yet the General Depart- 
ment for Planning and Urban Development, and if they do exist they are severally understaffed. One of the governors mentioned:

"the previous prime minster [referring to Dr. Ahmed Nazif] requested the GOPP to undertake the detailed plans for cities on our behalf when he realized the lack of the human resources that we are facing and how it impacts on citizens' ability to gain permits for building houses in the new expansion areas."

From the GOPP perspective, the building law is very clear in requesting local government to undertake the detailed planning process, and limiting the role of the GOPP to the provision of technical assistance and backstopping to local government. A senior official from the GOPP stated that:

"if we continue to undertake detailed plans on behalf of local government we will be working against the law. In addition, we are hoping the new law will provide a more decentralized approach in undertaking the plans by even pushing down the mandate of undertaking the detailed plans to the city level [not the governorate level]... many governors are asking us to undertake detailed plans on their behalf which is indeed an opposite trend of what the constitution and the government is aiming and hoping to achieve".

The debate around who should be undertaking the detailed plan is not the most important issue for most of the landowners interviewed. What really matters to them were how efficient is the process in allowing them to issue land permits swiftly, as they perceived the whole process to be inefficient and full of legal and administrative constraints. During a focus group, one of the landowners stated:

"land owners build illegally not because they want to disrespect the law or the process set by the government... it is in fact the process and the requirements stipulated in the law that became disrupted in a way that is not respecting the rights of land owners to use their assets or allowing them to secure a shelter for their sons and daughters".

Among the key constraints facing the preparation of the detailed plans and their relevance is related to land registration. Two important actors are involved in land registration; they are the Real Estate Publicity Department (El Shahr El Akary or El Segal El Aynee), and the Land Survey Authority (Hayaat El Masaha). The first actor is responsible for property title/deed registration, while the second is responsible for cadastral surveying. 
During the interviews with the senior officials for the GDPUD, they stated the coordination mechanisms between them and the actors involved in land registration are very weak. For instance they argued that they cannot access the records of the Real Estate Publicity Department and that the law or the executive regulation did not specify any institutional linkages or mechanisms that can allow them to do so. They also highlighted that the Land Survey Authority is under the Ministry of Irrigation and their local branches does not report to the governors technically or administratively, which limits the ability of the departments under the Governor to coordinate with them. The same situation is applies to the Real Estate Publicity Department which is under the Ministry of Justice.

The difficulties resulting from the lack of coordination is further escalated by the fact the information available regarding the ownership of the land in the new expansion areas is outdated or unavailable. The GOPP and local government argue that the availability of updated land registration records is crucial given the main aim of the detailed plans is to divide the whole expansion area into blocks, streets, and areas allocated for public services, and without having a complete record of land ownership, urban planners can create real conflict between land owners as some of them will be disadvantaged more than the others by the creation of roads, services, and other utilities created for the public good. A senior official at the GOPP mentioned that:

"if we completed a detailed plan without seeing land ownership, we may end up taking away the whole ownership of a citizen or dividing his ownership into small pieces that are not suitable for building... we can also benefit some land owners by having their land facing a major road while harming others by having their land near an undesirable service"

In 2006 The Egyptian Government started an ambitious project for building a Nationwide Cadastral Information System. This project has come to an end, however. During interviews with key officials from the Ministry of Justice and local government, they mentioned that the project's aim has not been fulfilled completely and there is a dire need to continue it with a focus on tackling the outdated legal framework governing land regeneration and titling, as well as the lengthy and complicated process of land registration.

Another key challenge facing the process of undertaking the detailed plans deals with the lack of clarity in the law and the guidelines regarding the process of undertaking these plans and how landowners will be compensated in case their land is taken away to create streets and other public services. Officials from the local government were divided into two groups, the first suggested that local government can use 
eminent domain to compensate land owners, while the other group was suggesting the land owners should donate one-third of their land, when they undertake land subdivision, for roads and public services, and this percentage should be enough for allocating the public services needed.

The head of GDPUD in one governorate suggested that the building law was not clear enough to tackle these conflicting views. He also suggested that this debate on the ground is meaningless as from one side, local government does not have the financial resources to use eminent domain and from the other side, land ownership has been fragmented in a way that most land owners do not have property large enough to be subdivided, and thus not allowing for a one-third of the land to be donated for public services. He stated:

"some people argue that we can use eminent domain to compensate the owners that have lost their land or use the betterment levy to do that. However, we receive no money from the central government to allow us to use eminent domain and the betterment levy has not been collected for ages and we do not think we can apply it now, especially in these circumstances [referring to the post $25^{\text {th }}$ of January Revolution]."

The frustration of landowners and local government officials was not only related to the lack of clarity in the methodology governing the process of undertaking the detailed plans, but also dealt with the relevance of the building regulations presented in the law. These regulations specify, among other criteria, the width of the streets, building heights, the percentage that should be allocated for open spaces, and the percent of the buildable area within the land plot. A senior official at the local government stated that:

"those consultants who are hired to develop the detailed plans are specifying building regulations as if they are planning a city in Europe and set very high standards and regulations. These experts are totally misunderstanding the context in the Egyptian cities and villages, the fragmentation of land ownership in Egypt, the dynamics of the housing market, and the informal building code se, and accepted by landowners and the small scale private developers. If the gap between the codes set by the detailed plans and those accepted by the land owners will not be narrowed down, we will continue developing plans that only looks like a nicely colored maps that are totally detached from reality".

Consultants on the other side argued that they are only following the standers presented in the building law and its executive summary, and the draft detailed plans that they produce will not be approved unless 
cleared by the GOPP and its regional offices which insures the adherence to the stipulated standers in the law.

One of the governors made a concluding remark regarding his perspective on the challenges facing the preparation and implementation of the detailed plans, he stated that:

"governors are in a very difficult position as they are requested to stop the illegal building, however the current legal and institutional framework does not allow the citizen to build legally.... It is us [the government] and our complex and irrelevant legislations that drive citizens to build informally and if we do not tackle this issue significantly, then we have no choice except to issue illegal permits or just turn a blind eye when land owners build informally".

\section{The application of the Betterment Levy}

The betterment levy is defined as a "compulsory charge imposed by a government on the owners of a selected group of properties to defray, in whole or in part, the cost of a specific improvement or services that is presumed to be of general benefit to the public and of special benefit to the owners of such properties" (IAAO, 1997). The application of this levy is present in many parts of the world, including developed countries like the United Kingdom, and in the developing countries like most Latin America countries.

The main aim of the levy is to generate a revenue base that assists the government, especially at the local level, in resolving fiscal space limitation when aiming at planning for infrastructure provision, as well as achieving progressive and redistributive outcomes from the capital gains resulting from the increment in property value that benefit certain classes of property owner as a result of governmental intervention (Latham, 1998).

The notion of 'betterment' or 'value capturing' is not new to the Egyptian legal framework as the betterment levy law no 222 was originally endorsed in 1955. The law stipulated that the levy could be applied if the government undertook construction, extension, and/or modification works of roads and plazas, sanitation projects, construction and/or modification of bridges, grade crossings, and tunnels, or any other intervention by the state that results in betterment and is approved by the Cabinet of Ministers. The building law added that property benefiting from the process of undertaking the detailed plans would also be illegible for the application of the levy.

Despite the long standing legal framework and the application of this levy in Egypt, most officials at the local governorate level are overlooking at its collection and/or assessing means to advance its cove- 
rage. In addition, very limited information is available on how this levy is collected in practice and the factors affecting its collection. Most respondents interviewed argued that if the collection of the levy was activated, it could assist in tackling some of the long-standing challenges facing Egyptian cities, like the provision of basic services and availing land for public services. Also several respondents from the GOPP and the local government argued that the amount collected would be substantive as the price of the one feddan [4,200 square meters] could change from around two hundred thousand Egyptian pounds to four million LE.

This research was able to document three interrelated findings regarding the application of the levy in Egypt, they are: the inconsistent application of the levy compared to law; the inadequate knowledge regarding the validity of applying it, especially in relation to the properties benefiting from undertaking the detailed plan in new urban expansion areas; and the hesitation of local government to collect, or expand in collecting the levy in the near future.

With respect to the first finding, the way local government applies the levy was found to be inconsistent with the law. For instance, in most governorates included in this research, the law stated that the levy should be either paid immediately in cash, or installed in ten equal annual installations or given as part of the property equivalent to the amount of the levy. However the levy is collected in practice when the property owner applies to local units requesting building permits or requesting the supplying of public utilities.

Another violation was found in several cities included in this research where the levy was applied to all properties within the city, and not on properties in specific sites. The local government argued that the government has provided various infrastructure projects which resulted in increases of property values within the city. However, the law was very explicit in the need for identifying the governmental interventions that has resulted in betterment. In an interview with a senior official in one of the governorates, he argued:

"this might not be the best way to calculate the levy that should be collected, but given the current limitation in the capacity of local government to form committees that assess the betterment resulting from each project... the levy imposed is about 1-6 LE for each meter square, which is a very modest estimate compared to the real betterment occurred as a result of governmental interventions".

The last violation reported was to the local administration law $\mathrm{n}^{\circ}$ 43 for the year 1979 whereby the governorates or the cities transferred the levy collected to local fund at the governorate or city level, 
instead of considering the levy as one of the cities' general revenues. This action cannot be understood without understanding the intergovernmental budgetary structure in Egypt. According to this structure, the governorate is the only local administrative level that is recognized as a budget authority. This means that the governorate is the only unit that has the power to negotiate with the Ministry of Finance during the process of preparing the state annual budget where the central government decides on the amount of the transfers that will be allocated to each budget authority to ensure that its ability to cover foreseen expenditures.

The implication of not acknowledging cities as budget authorities is that the head of the cities are forced to transfer all the revenues collected to the governorate level, which acts as a melting pot for the different revenues collected by the cities and other local units. This in turn either, minimizes their motivation and interest to collect the levy and any other general revenue as they are transferred to the governorate level, or motivates them to violate the law and channel the collected levy to special funds, that are under their control.

In a meeting with the head of the finance department in one of the cities he stated "if you are really requesting me to collect to apply the betterment levy, you have to tell me what is the incentive for me to collect it... all the revenues collected by the city are channeled to the governorate level. The governorate level revenues are a fraction of what is needed, and thus the central government has to provide a transfer that compensates this deficit. Heads of cities and villages do not see the value of applying the levy as they know that if they collected the levy they will not benefit from it directly, but if they did not collect it their deficit will be compensated by the central government"

With respect to the second finding, several local government officials interviewed were found to have inadequate knowledge regarding the legality of applying the levy, especially in relation to the properties benefiting from the detailed plan undertaken in new urban expansion areas. The exception was found to be in Ismailia governorate which took proactive steps and consulted the Legal Advice (Fatwa) Department of the State Council. The Legal Advice (Fatwa) Department concluded that the legislator:

"has decided overtly and frankly that the land undergoing improvement/betterment due to adoption of detailed plans of towns and villages - leading to its entry to the realm of boundary and consequently gaining hiking prices - shall be subject to imposed betterment levy whose rate will be determined in accordance with law 222/1955".

After receiving the legal advice, the Ismailia Governorate stared to 
collect the levy in new expansion areas and senior officials there believe it could support in tackling long-standing problems in expansion areas. During a focus group with key urban planning experts, that stated that most of the urban expansion areas that have been added to the cities are suffering from the availability of land for services, however most of the landowners will not be willing to donate land for building a school or any needed service by the community. One expert highlighted that:

"in most cases, it is very difficult to take a part of land from the land owners for services as the land is already fragmented as a result of Nasser's land reform. The most suitable case is to use eminent domain by expropriating the land from the land owners and compensating them with a fair price, which could be financed by the betterment levy".

A senior official from the GOPP attributed the leadership of the Ismailia Governorate to the investment made in the capacity of local government there and the leadership of several governors who managed the governorate in the past twenty years. He stated:

"we [the central government] should be blamed for the limited investment in the capacity of local government and not equipping them with the needed legal and technical skills that enable them to fulfill their mandates... the entrepreneurial example that is led by the Ismailia governorate is resulting from the accumulation of capacity building activities that have been undertaken in this governorates as a result of several urban development projects that were implemented by different donors and UN agencies... also the leadership and charisma demonstrated by several wellknown governors who managed the governorate had a significant impact on the attitude and capacity of employees there"

The final finding regarding the application of the levy in Egypt is related to hesitation of senior officials at the local level to collect, or expand in collecting, the levy. For instance, the Governor of Cairo was forced to withdraw his decision as a result of the complaints made by the property owners who were requested to pay the levy. His main argument that the decision was suspend in order to re-study and avoid loading citizens with additional burdens, especially after the significant increase in unemployment and inflation that resulted after the $25^{\text {th }}$ of January Revolution.

During an interview one of the governors stated:

"We have been discussing the application of the levy for two months now, but we are very hesitant to apply it in the new expansion areas. Our fear is that landowners will resist this dramatically. The situation after the revolution became 
so tense and we do not want to add more pressure". Another governor stated in an interview: "If I am not able to stop illegal expansion on the agricultural land, do you think I will be able to apply the betterment levy?... Landowners only feel that they have rights but they do not recognize that with rights comes responsibilities and the role of the government is to develop policies that insure social justice and equitable distribution of the government investments".

A senior official from the central government highlighted the impact of legitimacy of the state actors and the social contract between the state and the citizens when assessing reasons for the hesitation in collecting the levy. He stated:

"the whole challenge around applying the levy is similar to deciding to cutting fuel subsidies in Egypt... there are technical and capacity difficulties, but these issues are not the real problem... the real challenge is the legitimacy of the regime... during the last years of Mubarak rule, his legitimacy was at stake because of corruption cases, the rising inequity between social classes, and the prospects of having his son ruling the country... now after the revolution, the legitimacy is also the key factor but for different reasons, dealing mainly with the ability of the regime to represent the wider constituency and being able to deliver short-term results to restore the trust between the government and the citizens"

Some of the local planning experts highlighted the economic impact of the application of the levy and the potential correlation between the expansion in collecting it and the increase in land prices, which will eventually result in unaffordable housing. A senior local government official stated:

"the square meter suitable for building in many cities of the delta can reach ten and even fifteen thousands, in areas that are within the boundary but are built informally without a detailed plan. If the detailed plan was really applied as the law stipulates [with specific street width and building heights] and the betterment levy was applied, the prices of the houses will jump to levels that it becomes so unaffordable to the upper middle class in the delta".

During a focus group discussion, all landowners who benefited from the increasing prices of their land as a result of changing its land usage were not interested in paying the levy. One of the owners argued:

"we are the owners of this land and we don't see the point of the government sharing with us a profit that we 
made from an inheritance we acquired from our ancestors". Another owner added "it is the responsibility of the state to provide infrastructure and services, and for this reason the state collects taxes from us... If the government is really interested in collecting more resources, they should better search for the multi-millionaires who made fortune in no time and escaped from the country after the revolution."

Small-scale landowners and private developers highlighted that they do not feel that they are treated equally and fairly when they are requested to pay the betterment levy for instance. Their justification is that the neoliberal polices adopted by the state have resulted in subsidizing the provision of infrastructure land to benefit the elites in the new urban communities, and thus there is inconsistency in the way the state deals with the provision of infrastructure and the expectations from small scale developers working in the existing cities and large scale developers operating in the new cities.

\section{KEY FACTORS AFFECTING THE ACHIEVEMENT OF INTENDED OUTCOMES OF URBAN EXPANSION POLICIES IN EGYPTIAN CITIES}

Preliminary findings presented in this paper indicate that there are several key constraints that affect the ability of the Egyptian government to implement policies set to manage urban expansion. The below interrelated factors represent the starting point of a more in-depth research focusing on the role of institutions, defined by (Scharpf, 1997) as "a system of formal and informal rules that structure the courses of action that actors may choose", and the impact of the political economy within any given country on the process of implementation of urban expansion policies in cities of the developing world.

\section{Administrative, fiscal, and political centralization}

The move towards a decentralized government in Egypt has been considered by several scholars as being largely rhetoric, and what happens on the ground is either a stagnant form of a centralized institutional set-up or even at shift towards more centralization. This could be evident in the UGB policy and the shift from a decentralized approach, presented in Law $n^{\circ} 3$ for the year 1982, that empowers local government to specify the UGB with development partners at the local level, to a more centralized approach, as presented in the building law, that requires the GOPP to implement this policy with inputs from the local actors. 
Centralization is not restricted to maintain competencies at the central level, but in the case of undertaking the detailed plans, it was clear that the central government allocated this responsibility without clear identification of the budget that will enable local government to perform this mandate. In practice, and given the very limited capacity of local government to collect revenues, the implementation of the detailed plans remained as a product controlled by the GOPP.

The dependency on the central government is not only restricted to financial resources, but also in relation to human resources required to undertake the detailed plan. It was clear from the interviews that there is real shortage in number of well-trained technical staff, and in some governorates, the GDPUD does not even exist.

The very limited collection of the betterment levy presents a different perspective in relation to the impact of the fiscal centralization on the motivation of local government officials to collect local taxes and levies. The dependency of local government on central transfers and their inability to use them in a flexible manner (between budget line items and between years) created a powerful disincentive to collect these taxes and levies.

The rhetoric around political decentralization and the role of the local popular councils is mismatched with the current model of local administration in Egypt, which is very hierarchal in nature. The local administrative units are headed by civil servants appointed by the central government (with the head of the local administrative units at the village level who is appointed by the governor). This hierarchy and political centralization has reinforced upward accountability at the expense of representative democracy and the inclusion of citizens and non-state actors in the decision making process.

\section{Local government capacity}

Interviews with different local actors suggested that Governors' leadership is considered one of the key factors that effect on the implementation of the urban expansion policies. On one hand, their connection with different central agencies could have a great impact on expediting the process of undertaking the strategic plan and identifying the UGB. On the other hand, landowners and private developers suggested that their perception of how serious and committed the governor is in insuring the rule of law and preventing building outside the UGB or urban expansion areas without a detailed plan as the key deterministic factor influencing their decision to build illegally.

Several organization capacity challenges were noted in relation to horizontal linkages between key departments dealing with urban development of new expansion areas within the same local administrative 
units. The lack of coordination was also noted to be more profound with the actors outside the control of the governor (such as the offices of the National Survey Authority, the Real Estate Publicity Department, and other departments within the governorate).

Different informants attributed the weak coordination between the departments within the governorate or with other actors outside the direct control of the governor, to the rigid and fragmented institutional set-up and the lack of clarity of roles and responsibilities. Other informants suggested that the main factor is the norms and rules of the game that govern the performance of civil servants which drives them to be less included to cooperate with other departments to achieve common targets. This is mainly resulting from the: fragile performance management system that acknowledges and rewards outstanding performance and insures accountability in case of underperformance; the adoption of merit-based human resource management; and having a clear results-based monitoring and evaluation system.

Technical capacity was also noted to be very limited in key departments such as the GDPUD as most engineers interviewed are in a dire need of training on basic software essential for their work and do not have the needed hardware that enables them to perform their basic tasks. Staff working in the Real Estate Publicity Department and the Land Survey Authority at the local level are still using mostly paper, despite the government efforts to introduce the usage of computer software.

\section{Weak coordination and synergy between national plans and policies}

Several ministries and central authorities in Egypt are mandated to produce national plans and policies that have direct effects on urban expansion in Egyptian cites. The most prominent are: the National Socio-Economic Plan (produced by the Ministry of Planning); the National Strategic Spatial Plan (produced by the GOPP), and a set of sectorial plans and policies produced by the different sectorial ministries and central authorities. To date, a challenge facing the Egyptian government is how to ensure the coordination and synergy between these plans and policies.

A recent assessment was undertaken to explore the legal and institutional challenges that hinder the coordination between these plans and policies. It was concluded that the framework governing planning in Egypt (the Planning Law and the Building Law) is following two different and conflicting approaches to planning. On one side, the Planning Law integrates centrally between programs and projects, and finances their interventions through the state budget, however, with 
very limited spatial sensitivity and inclusion of development partners at the different levels. On the other hand, the Building Law spatially integrates between the interventions of the different ministries in a spatially sensitive manner but with no clear specifications on how their programs and the interventions will be financed (Nada \& El-Megharbel, 2012).

The lack of integration and connectivity between these two plans results in the allocation of investments by central ministries and agencies that might not be consistent (or might even be contradictory) with the national, regional, or local strategic plans. In term, this will result in the establishment of major infrastructure and investment projects in metropolises and cities facing high density and the challenge of expansion on agricultural land.

The Supreme Council for Planning and Urban Development was established, according to Building Law, with the aim of coordinating between ministries and other actors concerned with urban development and to endorse the objectives, and general policies for planning and urban development on the national level. However, since its inception, the council has not contributed significantly in synergizing between the different actors involved in the planning process nor the different policies and plans produced dealing with regional and urban development, and instead most decision taken by the council were seen as being predominately operational.

The absence of contemporary National Urban Policy (NUP) was seen by several experts as a key factor that restricts the synergy between the different national plans and policies. The only NUP that was drafted for Egypt was prepared in the 1970s and presented to the Ministry of Housing in 1982, and has not been updated since.

\section{Lack of clarity regarding the interpretation of the law and the skepticism regarding its relevance}

Evidence from the three case studies illustrated that laws set to implement the three polices are seen as being ambiguous and confusing. Several committees were established by the successive Ministers of Housing to suggest amendments to the building law and its executive regulation, and several changes were introduced in the executive regulation. Having said that, many legal and policy bottlenecks remain and there is no consensus around how to deal with them. Local administration law is also outdated and not reflective of the decentralization rhetoric presented by the central government.

The availability of manuals and training materials that describe the law and present case studies that interpret its articles were found to be generally missing. In addition, training course and other capacity buil- 
ding interventions are predominately restricted to senior staff.

\section{Land owners and private developer's unwillingness to comply}

The underlying assumption is that property owners and private developers will be motivated to comply with urban expansion policies if they perceive it to be relevant and fair in relation to their values, principles and inclinations, as well as their assessment of the repercussion of their noncompliance on their livelihoods.

Most property owners and private developers interviewed were not willing to comply with the three polices under investigation in this research. The reasons demotivating them varied to some extent according to the nature of the policy (being regulatory versus market-based), the capacity of the government to implement the policy, and their perception of the potential impact in case of non-compliance.

For instance, in the detailed plan, most informants stated that lengthy process of preparing and approving the city strategic plans and detailed plans is a major turn off factor. In addition, the complicated requirements needed for issuing licenses or permits, such as the provision of a proof of a registered ownership, was seen as being not feasible in the Egyptian context. Equally important, property owners were found to be generally confident that the state will not be able to hold them accountable if they violated the law and they were assured that they can get a way out through the prevalent red tape and extralegal practices.

In the case of the betterment levy, it was clear that property owners were not willing to pay the levy as they do not see its purpose and rationale. The use of awareness-raising as one of the policy approaches to manage urban expansion does not seem to be a government priority at the different levels. The renegotiation of the social contract between the state and property owners and reexamination the rights and responsibilities of the different actors was seen as a hypothetical and theoretical exercise that goes beyond the role and capacity of government, especially at the local level.

\section{Effectiveness of accountability mechanisms}

The initial findings from the two regulatory polices investigated demonstrate very weak accountability mechanisms employed by different actors. Svara (1990) pointed out that one of the key competencies that should be undertaken by local elected members is their representation ability, and she distinguishes between two forms of representation: the first is the ability is to act as a delegate for a special interest group and; the second is the ability to act as a trustee on achieving the public good for the entire constituency. These two roles should go side by side 
and the elected members are expected to use their judgment in taking decisions that lead to the decisions in favor of the best course of action.

Most citizens interviewed voiced that they were skeptical about how representative the members of the Local Popular Council were in relation to their wider consistency within the city or the village. Most citizens perceived their actions to be predominately motivated by selfseeking interest and that their main locality is to their close relatives and family members, and thus not fulfilling their trustee role.

Skepticism in the capacity of local government was not only restricted to the role of the elected members, but also to the capacity of the civil servants to insure the application of the law was also noted from the interviews. In general, landowners feel the local government is not in a position to control informal development, especially with the huge financial gains generated from changing the land from arable to urban land. Several cases of corruption in local government were also reported during the interviews and many landowners and private developers are stating that they are normally incorporating the cost of briberies in their budgets.

National entities mandated for inspecting on local government performance and the building regulation are also perceived by the local government officials and land owners interviewed to be very fragile and centralized. An interview with a senior official in the Organization for Inspecting on Construction Work revealed several organizational challenges related to the limited human resources the organization has which is reflected at the limited outreach in the different cities and villages. In addition, we also noted very limited coordination with other actors involved in the inspection on local government.

Several youth and civil society initiatives that aim at tacking corruption in local government were noted on social networking websites. However citizens, landowners, and private developers interviewed were not aware of these initiatives or their impact on the ground. Further research is needed to map out these initiatives and assess their strategies and how they are perceived by the different actors.

\section{The wider political environment}

Egypt moved away from state socialism and Nasser's post-colonial nationalism with the beginning of President Anwar el Sadat (19701981 ) and his Infitah policy that aimed at encouraging foreign direct investment and better integration into the global market. This policy intensified during President Hosni Mubarak who, in the mid-1980s, adopted a wide range of economic reforms and structural adjustments, which made Egypt one of the Middle East's most prominent emerging economies and resulted in the creation of a record number of jobs (World Bank, 2009). Remittances from Egyptian working in Libya and 
the Gulf countries remained and expanded during that era and had a very important impact on financing cities' urban expansion, which was predominately informal (Singerman, 2011).

Amid this relatively favorable economic performance, inequity between the rich and the poor has been on the rise and the absolute number of poor people has been increasing. In addition, with the economic liberalization the state started to withdraw from the provision of basic services (Yacobi and Shechter, 2005).

Opposition movements in the 1990s, mainly Islamist in orientation, started to gain momentum and power as a result of the state-adopted neoliberal policies, which resulted, among other factors, in a popular apprising on the January 25, 2011, that toppled Mubarak's regime and brought the Muslim Brotherhood to power. The rule of the brotherhoods gave little official attention to urban governance and the regime did not last for long as it was toppled was toppled by the military supported by popular demand and backstopped by key influential actors in Egypt and in the region.

The successive authoritarian and exclusionary regimes over the past four decades had a significant impact on the social contract between the state and the citizens; the role of different actors within the country; the perceived legitimacy of the state by citizens; and the ability of the state to enforce legislations and the rule of law (Bradley, 2008; Osman, 2010; Singerman, 2011). Dorman (2013) presents an in-depth analysis of the Egypt's changing political economy since the beginning of the Nasser era, the impact on urban development in the country, and argued that "Cairo's trajectory is best understood in the context of a durably authoritarian political order, rather than as Egypt's fitful experiment with economic liberalization."

\section{CONCLUDING REMARKS}

The lack of the government capacity to achieve the intended outcomes from the policies investigated in this research cannot be understood without critical examination of the long history of centralization and its impact on actors' behavior at the different levels. Central authorities have created and maintained interest in maintaining and increasing their power on the expense of local government, and the shift towards more centralization cannot in itself be understood without analyzing the power dynamic between the different actors at the central level and their interest to defend and expand their powers.

Evidence from this research argues that the central government has been traditionally maximizing their power at the expense of local government, and while the rhetoric in the past decade has been in favor 
of the shift towards a more decentralized government, in reality, central actors are in fact pushing towards more centralization.

Local government, on the other hand, is suffering from a very limited capacity to manage urban development or the provision of services. They are not motivated, especially after the Revolution, to call for a more decentralized government. To governors, maintaining power with the central government reduces the pressure on them and provides a good excuse for poor delivery. Landowners and private developers trust in local government capacity - both in elected members of the popular council and civil servants - cannot be explained without fully capturing the role of the context and impact of the authoritarian regime that has be governing Egypt since Nasser's time, and the very limited space for civic engagement and social accountability.

Finally, this research suggests that the decisions of land owners and private developers to develop informally cannot be seen as an ignorant act, but in fact a decision made by rational actors who are concluding that the benefits gained from building informally outweighs the gains from following the complicated and inefficient formal route. 
MOHAMED NADA dirige le programme «Politiques et Gouvernance Urbaine » de UN-Habitat Egypte. II a étudié I'environnement et le développement à l'école d'études du développement, Université de East Anglia, Royaume Uni, et est actuellement doctorant à l'école de gouvernance et politiques publiques, université de Maastricht, Pays-Bas.

Il a rejoint UN-Habitat en 2009 pour piloter un projet visant à réformer le cadre légal et institutionnel de la planification et de l'urbanisme. Il possède une longue expérience des champs de la gouvernance et de la planification urbaine aux échelons local et régional, avec une expertise dans l'analyse institutionnelle, les politiques publiques territoriales, le développement régional, la capacitation des jeunes et des femmes, et les dispositifs participatifs.

Il a animé et/ou participé à un grand nombre de comités techniques ou consultatifs pour différents ministères, institutions gouvernementales et nongouvernementales. Il est également membre de conseils d'administration de plusieurs organisations non-gouvernementales, dont Nahdet el Mahrousa et Friends of the Environment à Alexandrie.

MOHAMED NADA is the Program Manager of the Urban Policies and Governance Program at the UN-Habitat Egypt. He studied Environment and Development at School of Development studies, University of East Anglia, UK, and is currently a PhD research Fellow at School of Governance and Public Polices, University of Maastricht., the Netherlands.

He arrived at UN Habitat in 2009 to lead a project that aims at reforming the legal and institutional framework governing planning and urban development. He has wide experience in urban governance and planning at local and regional levels, with expertise on institutional analysis, territorial public policies, regional development, youth and women empowerment, and participatory mechanisms.

He has facilitated and/or participated in a number of advisory and technical committees to different ministries, governmental and non-governmental institutions. He is also a Board member in a number of non-governmental organizations, including Nahdeat el Mahrousa, Friends of the Environment in Alexandria. 


\section{REFERENCES}

Angel S., Sheppard S. \& Civco D., 2005, "The Dynamics of Global Urban Expansion." Transport and Urban Development Department, The World Bank.

Bengston D., Fletcher J., \& Nelson K., (2004) "Public Policies for Managing Urban Growth and Protecting Open Space: Policy Instruments and Lessons Learned in the United States." Landscape and Urban Planning 69: 271-86.

Cervero R., 1995, Planned communities, self-containment and commuting: a cross-national perspective. Urban Studies, 32(7), 1135-1161.

El Araby M., 2002, "Urban growth and environmental degradation: The case of Cairo, Egypt." Cities 19(6): 389-400.

Holus L.E., Fulton W., 2002, Open space protection: conservation meets growth management. Discussion Paper. Center on Urban and Metropolitan Policy, The Brookings Institution.

IAAO (International Association of Assessing Officers). 1997. Glossary for property appraisal and assessment. Chicago, IL: IAAO.

Levinson D. M., \& Kumar A., 1997, Density and the journey to work. Growth and Change, 28 (2), 147-172.

Myers P., 2001, Growth at the ballot box: electing the shape of communities in November 2000. Discussion Paper. Center on Urban and Metropolitan Policy, The Brookings Institution, Washington, DC.

Nada M., \& El-Megharbel N., 2012, "The Legal and Institutional Framework Governing Planning in Egypt: key challenges and the way forward", The Institute of National Planning.

Scharpf F., 1997, Games Real Actors Play: Actor-centered Institutionalism in Policy Research. Theoretical Lenses on Public Policy series. Boulder and Oxford: HarperCollins, Westview Press.

Schwanen T., DiJst M., \& Dieleman F. M., 2004, Policies for Urban Form and Their Impact on Travel: The Netherlands Experiences. Urban Studies, 41(3), 579-603.

Singerman D., 2011, Cairo Contested: Governance, Urban Space, and Global Modernity. The American University in Cairo Press.

Svara J. H., Official Leader ship in the City, New York: Oxford Univer sity Press, 1990, p. 126.

Thomas L., and Cousins W., 1996, "The Compact City: A Successful, Desirable and Achievable Urban Form?" in Jenks M., Burton E. and Williams K., eds., The Compact city: A Sustainable Form? London: E\&FN Spon, 56.

Yacobi H., and SheChter R., 2005, "Rethinking Cities in the Middle East: Political Economy, Planning, and the Lived Space." The Journal of Architecture 10:5, 499-515. 